\title{
Urdimento
}

Revista de Estudos em Artes Cênicas

E-ISSN: 2358.6958

\section{Portas Poéticas: espaço para a imprevisibilidade poética em cena}

Nitza Tenenblat

\section{Para citar este artigo:}

TENENBLAT, Nitza. A concepção de Cenografia que cria diferentes conexões entre edifício teatral e cidade. Urdimento, Florianópolis, v. 2, n. 38, ago./set. 2020.

DOI: http:/dx.doi.org/10.5965/14145731023820200037

Este artigo passou pelo Plagiarism Detection Software | iThenticate 
Portas Poéticas: Espaço para a Imprevisibilidade Poética em Cena

Nitza Tenenblat ${ }^{1}$

\title{
Resumo
}

Este artigo examina a ferramenta denominada porta poética como dispositivo performativo de abertura espaço-temporal para a imprevisibilidade poética coletiva em cena. Apresenta como foi desenvolvido, sua definição e exemplos aplicados nos espetáculos O Amor Que Habito (2018), Uma Sonata Familiar (2018) e Luar de Contos (2019) da Coletiva Teatro. Em espetáculo com encenação definida, abre-se espaço para desvios com o objetivo de intensificar o momento dramático, possibilitando múltiplas novas camadas de significação em tempo real que emergem no e do encontro entre artistas e público. Investiga-se o grau de liberdade poética e performativa do dispositivo bem como as condições necessárias e implicações dramatúrgicas do seu uso. Artista e público tornam-se reconfiguradores contínuos de singularidades poéticas.

Palavras-chave: Porta poética. Coletiva Teatro. Dispositivo performativo. Criação em coletivo.

\section{Poetic Doors: Space for the Poetics of Unpredictability on Stage}

\begin{abstract}
This article examines the tool denominated poetic door as a performative device that opens space-time opportunities for the poetics of the collective unpredictability on stage. It presents how it was developed, its definition and applied examples in the productions O Amor Que Habito (2018), Uma Sonata Familiar (2018) and Luar de Contos (2019) by Coletiva Teatro. In a blocked performance, space for deviation is created with the goal of intensifying a given dramatic moment, enabling multiple new layers of meaning in real time that emerge during and as a a result of the encounter between artists and audience. The degree of poetic freedom and performativity of the device are investigated as well as the required conditions and dramaturgical implications of its use. Artist and audience become continuous reconfigurators of poetic singularities.
\end{abstract}

Keywords: Poetic door. Coletiva Teatro. Performative device. Collective creation.

Profa. Dra. Programa de Pós-graduação em Artes Cênicas (PPGCEN) e graduação em Artes Cênicas, Universidade de Brasília (UnB). nitzatenenblat@gmail.com 
Muitas reflexões e análises fecundas têm sido realizadas sobre os aspectos performativos no teatro contemporâneo desde os escritos sobre o teatro pósdramático (Lehmann), o teatro performativo (Féral e Fabião), o teatro enquanto tríade convivência, poiésis e expectação (Dubatti) e ainda o poder transformador da performance no teatro (Fischer-Lichte). Na sua esmagadora maioria, estas reflexões e análises se baseiam na descrição de determinados elementos encontrados em espetáculos e performances que sugerem, respaldam e/ou atestam para a existência de novos conceitos e rumos experienciados a partir da cena. Assim, no âmbito da produção de conhecimento nas artes cênicas contemporâneas, graças a inúmeras contribuições, hoje pode-se identificar o que é e quais são algumas das características encontradas no que denominamos teatro performativo.

Infinitamente menor, no entanto, é o número de reflexões e análises que sistematizam ferramentas e dispositivos que geram performatividade em cena. Estes, além de serem fundamentais para que as análises e reflexões conceituais mencionadas anteriormente sejam possíveis, quando sistematizados, possibilitam uma ampliação e aprofundamento do nosso conhecimento sobre as tecnologias que geram estéticas performativas. E reconhecer e sistematizar tecnologias de estéticas performativas permite explorar a performatividade em cena de forma mais consciente e crítica, expandindo a sua acessibilidade, uso e potencial de impacto transformador.

Segundo Fischer-Lichte (2008) uma das principais características da estética performativa é a autopoiesis gerada pela mútua interação entre artistas e espectadores. Para esta autora, a poética própria gerada por essa interação engendra performance e o fenômeno da emergência. Mas a qualidade da interação entre artistas e espectadores pode variar imensamente e nem tudo que emerge a partir do convívio e expectação durante a interação encontra respectiva significação cênica numa apresentação. É preciso criar, materializar e permitir condições espaço-temporais para que essa interação ocorra; assim como é preciso também abrir espaços-tempos para que o que emerja a partir e/ou durante esta interação ganhe significação cênica. Então surge a dúvida: como gerar 
performatividade cênica significativa? Isso pode e é realizado de inúmeras formas, mas, como argumentado anteriormente, a identificação conceitual por si só destas formas é insuficiente para que possamos realizá-las em cena.

Este artigo se propõem a sistematizar o dispositivo técnico e criativo denominado portas poéticas como uma possibilidade autopoiética que utiliza o fenômeno da emergência, ou seja, tudo aquilo que emerge da e na convivência entre artistas e espectadores em prol da performatividade e em diálogo com a significação cênica. Neste caso, o dispositivo não se limita à autopoiesis gerada entre artista e espectador, como propõem Fischer-Lichte, mas inclui também a gerada entre artistas e entre espectadores. Além disso, e em contraste com a performatividade teatral concentrada na função do ator, este dispositivo se revela como uma possibilidade para outras funções, desde que participem da execução da performance. Finalmente, também em contraste com muitos dispositivos técnicos criativos para o teatro, treinados e executados individualmente, este se dá de maneira altamente coletivizada, fazendo do coletivo o seu meio de treinamento e realização.

Mas, como tantos outros, este dispositivo técnico e criativo surgiu muito distante destas reflexões conceituais que hoje, a uma certa distância e depois de muita experimentação, são possíveis. Surgiu dentro da sala de ensaio, em meio a um processo criativo.

\section{Portas poéticas em contexto}

Durante a criação do primeiro espetáculo autoral da Coletiva Teatro chamado O Amor Que Habito em janeiro de $2017^{2}$ surgiram duas demandas artísticas aparentemente opostas. Por um lado havia no coletivo o interesse em utilizar a técnica estadunidense dos Viewpoints (Bogart e Landau, 2005) para explorar e compor cenas que estavam sendo criadas, marcadas e definidas para o

O processo criativo do espetáculo foi iniciado em 2015 com estreia e temporada em abril de 2018 no Centro Cultural Banco do Brasil, Brasília. Faz parte do repertório do grupo e continua sendo apresentado desde então. Mais informações em http://www.coletivateatro.unb.br/index.php/pt/acoes-artisticaspt/espetaculos-pt/o-amor-que-habito . 
espetáculo; por outro, havia o interesse em utilizar a técnica e o frescor das explorações dos Viewpoints em tempo real durante a apresentação, como linguagem estética do espetáculo. Como diretora do espetáculo, tendo em vista o caráter improvisacional e exploratório da técnica de Viewpoints e a previsibilidade necessária na encenação para a coerência de discurso do espetáculo teatral, a capacidade de atender simultaneamente a esses dois interesses me parecia contraditória e divergente. No entanto, o desafio de tornar esses dois elementos compatíveis permitiu a descoberta de um dispositivo técnico-criativo para teatro performativo que literalmente abre espaço para momentos poéticos imprevisíveis em cena, possibilitando múltiplas e novas camadas de significação em tempo real que emergem no e do encontro entre artistas e público. Hoje as portas poéticas fazem parte do repertório técnico-criativo da Coletiva Teatro, estão presentes em diversos trabalhos artísticos, inclusive os com colaboração internacional, portanto já desbravaram as fronteiras do intercâmbio de conhecimento teatral, e são um importante instrumento de singularidade, liberdade e diálogo criativos simultaneamente individual e coletivo.

A trajetória até a sistematização deste dispositivo envolveu o enfrentamento de diversos desafios, muitos deles velhos conhecidos do universo da criação teatral. Entre eles, como manter a potência latente, o frescor e vigor do improviso sem perder a contundência, precisão e solidez advindas das inúmeras repetições e respectivos refinamentos realizados para a versão final das cenas? Como manter uma equipe teatral envolvendo atores, técnicos, assistentes e diretora conectados e contribuindo em tempo real para uma cena com a sua respectiva atividade de maneira coerente e complementar, se alguém poderia a qualquer momento improvisar algo imprevisível e inesperado na cena previamente definida? E a dramaturgia de um espetáculo que adotasse esses dois interesses simultaneamente, no que se transformaria? E finalmente, talvez o desafio mais delicado de todos: a plateia seria capaz de acompanhar e se conectar com uma dramaturgia com essa natureza ou perderíamos a história que tentávamos contar?

Foi dentro deste contexto e com o objetivo de responder às questões acima que a Coletiva Teatro desenvolveu o dispositivo técnico e criativo que 
denominamos portas poéticas, principal foco deste artigo. Mas antes de descrever como as portas poéticas satisfazem à primeira questão (imprevisibilidade versus previsibilidade) e geram desdobramentos e consequências sobre a equipe criativa e a dramaturgia, é importante observar que o desenvolvimento das portas poéticas se deu como parte da pesquisa prática coletiva do grupo no projeto Exercícios de Criação em Coletivo para a Cena, cujo objetivo principal é o estudo da coletivização de procedimentos cênicos do ponto de vista estético, poético, político e/ou ético. Dentro deste projeto, o surgimento das portas poéticas seguiu o fluxo de uma prática de pesquisa técnica e rigorosa mas muitas vezes caótica e não-linear uma vez que também é artística e criativa. Assim, a organização e estrutura presentes neste artigo, embora distintos da cronologia de fatos original, buscam uma descrição clara do dispositivo incluindo sua função, vantagens e desvantagens, na esperança de que seja útil a outros artistas e/ou coletivos que se interessam por dispositivos de teatro performativo. Os momentos de incerteza e confusão tão presentes numa prática de pesquisa que depende da percepção de corpos, suas inter-relações e expressões criativas - tão fugazes quanto instáveis e variáveis mas não por isso menos identificáveis e sistematizáveis - foram excluídos, exceto quando estes serviram para esclarecer ainda mais o dispositivo em si.

Além disso, o desenvolvimento das portas poéticas se deu concomitantemente à criação de outros três dispositivos técnicos coletivos usados pelo grupo denominados de personagens líquidos, multiplicidade e cisão (que não caberiam neste artigo mas serão objeto de trabalhos futuros) e também paralelamente mas não deslocado dos projetos individuais de pesquisa de membros da Coletiva Teatro. Isso significa dizer que embora este artigo seja escrito por uma única membro da Coletiva Teatro, o seu conteúdo é a destilação de uma quantidade muito maior de material criativo e de pesquisa prática realizada em coletivo mas que só foi possível porque também esteve intimamente imbricado e polinizado pelas pesquisas práticas sobre a transição de e entre personagens e ator como potência criativa no trabalho de atuação de Nei Cirqueira; a contação de histórias pela perspectiva de Jorge Marinho; e a vulnerabilidade no processo criativo na Coletiva Teatro pelas perspectivas de Pedro Lopes e Alexandre Batista. 


\section{Uma definição e alguns exemplos}

O que vem a ser uma porta poética? Uma porta poética é o nome dado ao dispositivo técnico e criativo que define, durante uma performance em tempo real, um espaço-tempo momentâneo imprevisto mas proposto de maneira proposital, improvisada e temporária que se distingue da encenação previamente definida e tem o objetivo de intensificá-lo ou potencializá-lo. Pode ser inicialmente provocado por qualquer ator e/ou técnico da equipe cênica de forma individual ou coletiva, desde que tenha início e finais claros e reconhecíveis para todos os artistas participando da apresentação. Assim, usamos o terminologia "abrir uma porta poética" quando alguém inicia um movimento de afastamento da encenação e respectivas marcas cênicas previamente definidas para abrir espaço para algo novo; e "fechar a porta poética", quando esse momento novo criado chega ao fim e todos retomam novamente a encenação reconhecida como previamente definida e marcada. Ou seja, este é um dispositivo criativo coletivo performativo que permite e delimita a fuga imprevista e respectivo retorno a uma encenação pré-estabelecida que pode ser provocado intencionalmente por um ou mais integrantes de uma equipe criativa. É importante observar que as portas poéticas são reconhecíveis apenas para a equipe criativa que a realiza ou alguém que conheça o espetáculo. Caso contrário, funcionam como partes integrantes do espetáculo em questão.

Mais interessante (e menos confuso) do que pinçar os momentos de lenta descoberta, aprofundamento e entendimento do que estávamos tentando alcançar ao desenvolver este dispositivo, entendemos que seja mais útil demonstrar a sua utilização, dando exemplos práticos de como ele foi e continua sendo aplicado. E embora ele atualmente seja utilizado em diversos projetos e trabalhos com resultados estéticos da Coletiva Teatro, o espetáculo O Amor Que Habito serviu como ponto de partida para o seu desenvolvimento e por isso abunda em exemplos e oportunidades de análise coletados ao longo de diversas apresentações que serão aproveitados no presente artigo. 
O Amor Que Habito é um espetáculo sobre encontros com a alma em tempos de modernidade líquida. O texto foi fruto da indagação inicial sobre como é encontrar-se com a sua própria alma na esfera do amor e foi inspirado pelos seguintes textos que lidam com o amor, a alma e a existência: Da Morte e Metafísica do Amor (2001) de Arthur Schopenhauer; Amor Líquido (2003), de Zygmunt Bauman; Alma Livre (2009) de Michael A. Singer; As Intermitências da Morte (2005) de José Saramago e Amor para Corajosos: Reflexões Proibidas para Menores (2017) de Luiz Felipe Pondé. O espetáculo conta a história dos encontros e desencontros amorosos entre um Porteiro viciado em café; seu Pai, um Coveiro obstinado; Dona Berta, uma senhorinha simpática; a Morte; Ana Luiza, uma moça perdidamente apaixonada; e quatro atores que se revezam interpretando-os. As histórias em âmbito ficcional das personagens são entrelaçadas às revisitações de episódios autobiográficos dos atores, e todos aventuram-se a responder de suas respectivas perspectivas, uma única pergunta: qual o amor que eu habito? $\mathrm{Na}$ tentativa de tornar suas almas mais lúcidas diante do amor, se questionam: será que é tempo de amar?

Vejamos um primeiro exemplo de uso de porta poética neste espetáculo. Logo na primeira cena, Ana Luiza chega ao apartamento do homem por quem está perdidamente apaixonada para the fazer uma surpresa mas descobre com o Porteiro que ele se mudou recentemente. Neste momento, três atores dispostos em lugares diferentes no palco (sinalizados com fachos de luz simbolizando a porta do apartamento) interpretam a personagem Ana Luiza e um ator interpreta o Porteiro. 


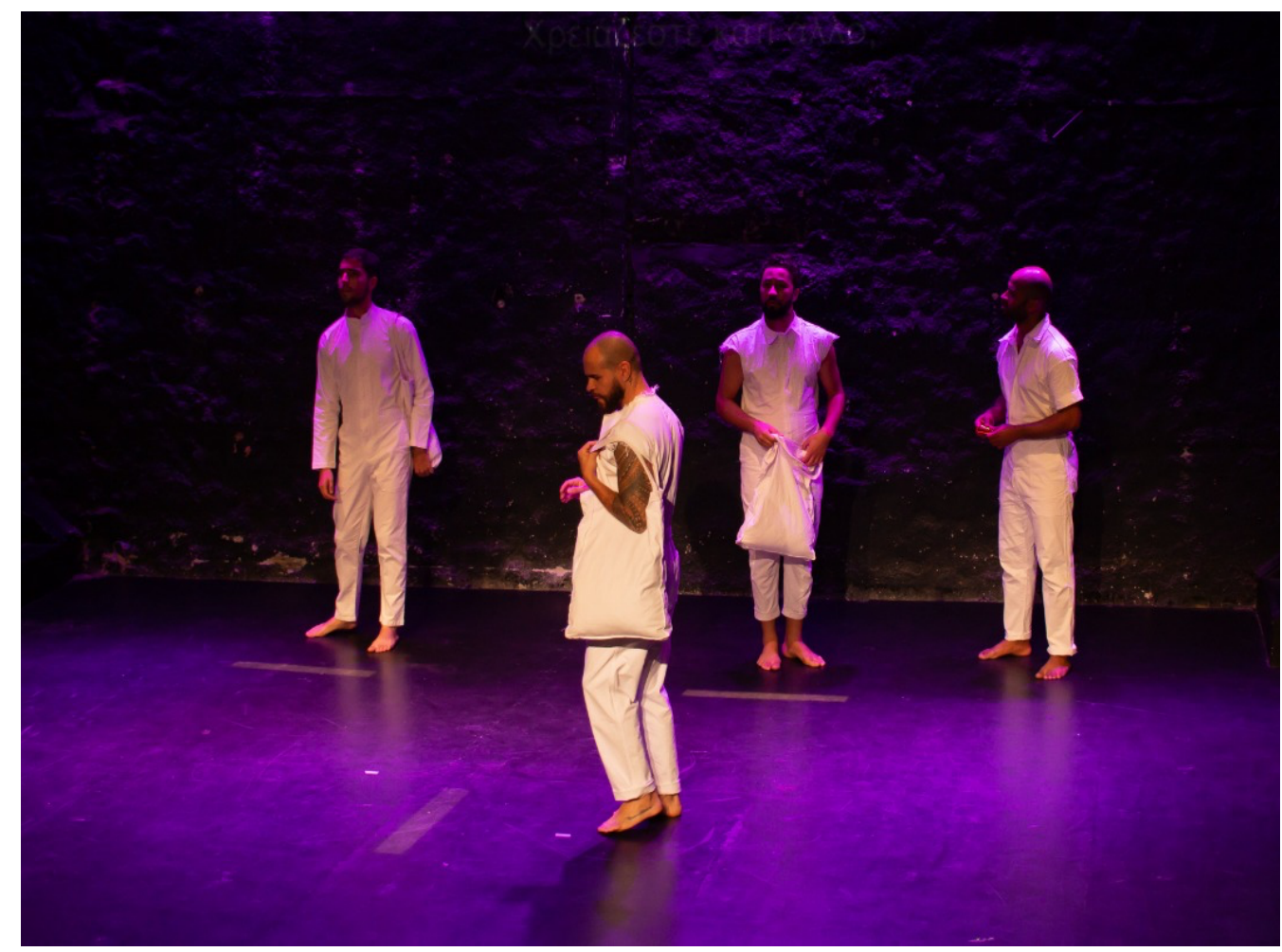

Depois de vasculhar em vão por algum vestígio do rapaz dentro do apartamento aberto pelo Porteiro apiedado, Ana Luiza arrasada desaba em seus braços. O texto segue da seguinte maneira:

Ana Luiza (se recompondo) - Desculpa. (Ela entra no banheiro e limpa o rosto. Do lado de fora, Porteiro fica inquieto.)

Porteiro (na porta) - Você está bem?

Ana Luiza - Está tudo bem. Eu já estou saindo. (se recompõe e sai)

Porteiro (admirado) - Você é linda.

Ana Luiza - Você que é e não sabe

Numa determinada apresentação um dos atores que interpretava a Ana Luiza, logo após o texto: “Está tudo bem", incluiu o texto" "É que eu vim fazer uma surpresa, sabe?", dito somente para si em tom de sussurro enquanto olhava seu

${ }^{3}$ Da esquerda para a direita Jorge Marinho, Nei Cirqueira e luri Persan interpretando Ana Luiza e Pedro Lopes interpretando o Porteiro na chegada ao apartamento. 
reflexo no espelho imaginário do banheiro. Ao se desviar do texto original repetindo uma frase dita anteriormente pela Ana Luiza ao Porteiro, o ator abriu uma porta poética. O desvio proposto neste caso foi textual e criado usando o viewpoint de repetição. Sugeria uma autorreflexão da personagem sobre como ela havia chegado àquela situação. Os outros atores que também interpretavam a Ana Luiza aceitaram o convite da porta adentrando a poesia que ela inspirava e complementaram e aprofundaram ainda mais a autorreflexão da personagem com os seguintes recursos: a) a repetição da frase: 'É que eu vim fazer uma surpresa, sabe?' acrescida da repetição e intensificação da ação (na rubrica) de limpar o rosto ao se ver no espelho; b) a quebra da $4^{a}$ parede e pergunta direta a alguém da plateia: 'você já fez uma surpresa?'; c) a repetição da frase: 'Está tudo bem' com a intenção de se convencer do conteúdo da frase diante da imensidão da crise.

Por alguns instantes o que originalmente era uma pausa breve no banheiro para se recompor, se tornou um momento de grande intensidade, complexidade e intimidade emocional, ampliando, multifacetando e aprofundando a autorreflexão e crise da personagem. Alem da quebra de $4^{a}$ parede, o viewpoint de repetição, neste caso aplicado ao texto, se revelou muito potente na criação desta porta poética. Como a frase: 'É que eu vim fazer uma surpresa' já havia sido dita anteriormente pela Ana Luiza ao Porteiro no início da cena, sua repetição no contexto da intimidade do banheiro intensificou a falência do seu propósito em estar ali sem a presença do amado para quem a surpresa tinha sido planejada. Ao mesmo tempo a repetição da frase permitiu um retorno à primeira vez que Ana Luiza a disse ao Porteiro, antes de descobrir que o apartamento estava vazio, como se necessitasse se agarrar àquele momento no tempo; como se ao repetir a frase, pudesse negar a informação recebida e a consequente desilusão. A repetição concomitante do outro ator da frase: 'está tudo bem', aumentava ainda mais a sensação de que de fato, nada estava bem para a personagem em crise.

O fechamento desta porta poética se deu quando um dos três atores que interpretava a Ana Luiza disse: 'Eu já estou saindo', interrompendo os sussurros, retomando o texto original da cena e indicando a todos que estava fechando a 
porta poética que tinha sido aberta. Os outros dois atores que interpretavam a Ana Luiza saíram com ele e todos retomaram a cena que haviam se permitido temporariamente aprofundar.

Neste exemplo, três dos quatro atores em cena geraram uma porta poética abrindo espaço para intensificar o momento dramático de autorreflexão da personagem Ana Luiza. Mas o que ocorreu com o ator que interpretava o Porteiro enquanto os outros três atores improvisavam a Ana Luiza em crise? Ele não podia continuar a cena pois o texto seguinte não lhe pertencia. Tão pouco faria sentido ficar paralisado e interromper o fluxo da cena. Neste caso o ator optou por se manter improvisando a circunstância interna da sua personagem proposta na rubrica do texto (inquietude) até o fechamento da porta poética pelos seus parceiros, para retomar, junto com eles, o restante pré-estabelecido da cena.

Este exemplo traz uma característica importante das portas poéticas enquanto dispositivo: nem todos precisam entrar numa porta poética aberta; esta é uma escolha criativa que precisa ser reconhecida por todos, que afeta a todos, mas que deve considerada individualmente como opção artística no momento em que ocorre. O primeiro movimento da porta poética é a abertura de um espaçotempo para possibilidades; o que será feito com esse espaço-tempo é outra questão. Em outras palavras, embora seja um dispositivo realizado coletivamente há muita liberdade poética e criativa individual diante de uma porta. Cria-se, entrase e sai-se de uma porta poética se e quando se quer, de maneira imprevisível, desde que respeitadas a sinalização clara para todos destes momentos (garantindo assim a consciência e opção a todos) bem como mantendo a integridade da história e a dramaturgia originais em curso, que atuam como delimitadores e norteadores mas jamais limitadores. Todos precisam saber em que momento dramático o coletivo está na encenação, no texto/roteiro e marcas (de todas as funções) para não haver repetição indesejada da história e/ou saltos e/ou descompasso por falta de fluidez. Por outro lado, toda porta poética implica necessariamente numa tomada de decisão por todos da equipe criativa, independentemente de qual função ocupem. A despeito da imprevisibilidade, no momento que um artista propõem uma porta poética, atores, iluminador, 
contrarregras, sonoplasta, etc. têm que decidir como irão dialogar com a proposta. Vejamos outro exemplo.

No final desta cena o Porteiro, comovido com a situação da Ana Luiza que não tem para onde ir, permite que ela passe clandestinamente a noite no apartamento vazio. Depois de uma noite difícil para Ana Luiza, lê-se na rubrica o momento ficcional seguinte:
... Às 5:30 da manhã o Porteiro se arruma para se encontrar com ela. (Leva café fresquinho. Bate levemente na porta. Ao não ser atendido, abre a porta cuidadosamente.)
Porteiro - (para Ana Luiza, que dorme) Eu fiquei pensando naquilo que você me falou. A noite toda.
(Porteiro dança seu encantamento por Ana Luiza)
Porteiro - Moça...moça...? Eu trouxe café.

Neste momento uma marca da cena inclui a entrada silenciosa do Porteiro no apartamento onde encontra Ana Luiza adormecida no chão, novamente interpretada por três atores posicionados em locais diferentes.

Figura 2 - O Amor Que Habito, 2018, Texas, EUA. Foto de Thiago Sabino4

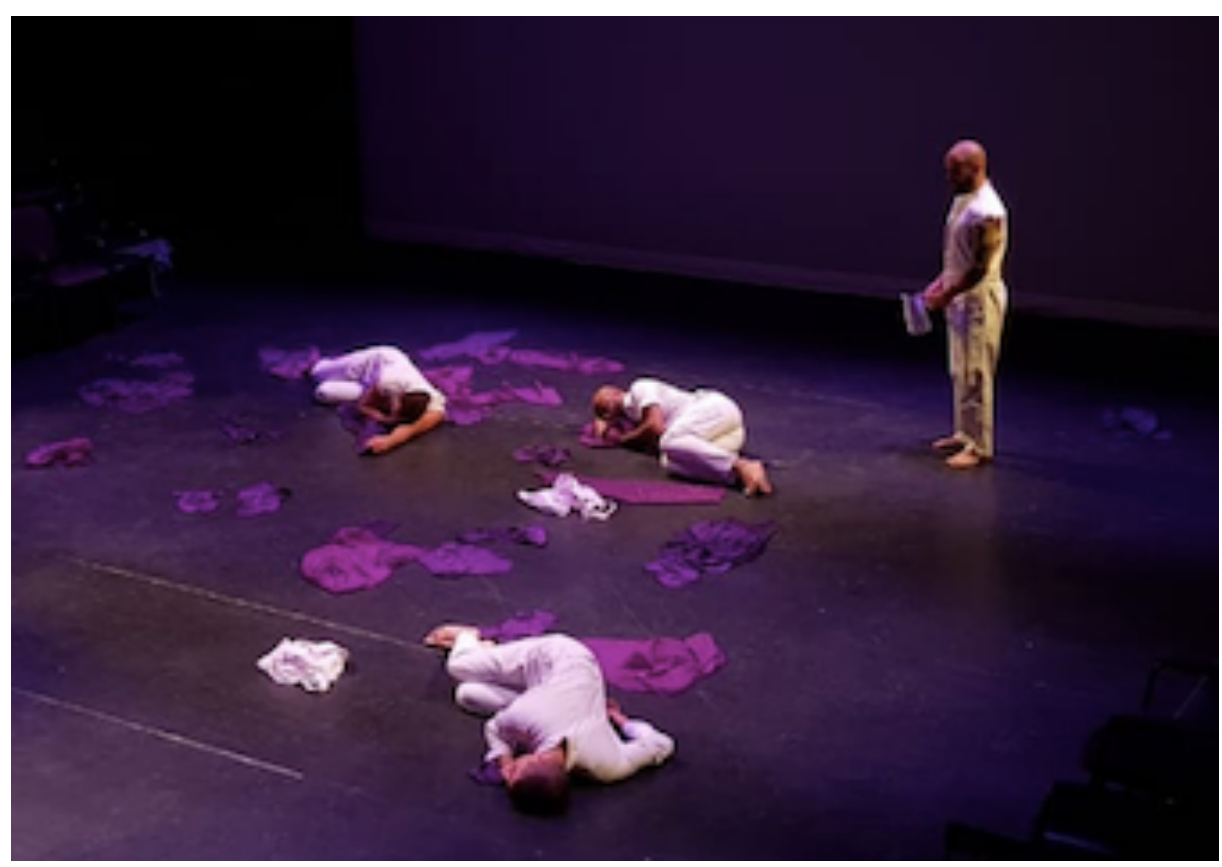

${ }^{4}$ Da esquerda para a direita luri Persan, Jorge Marinho e Pedro Lopes interpretando Ana Luiza e em pé Nei Cirqueira interpretando o Porteiro. 
Várias portas poéticas diferentes já foram criadas neste momento de dança do Porteiro e sono pesado da Ana Luiza. Um exemplo foi quando um dos atores que interpretava Ana Luiza, ao sentir a aproximação do Porteiro, levantou-se, o beijou e em seguida se derreteu novamente ao chão, retornando à posição exata que estava quando dormia. Esta porta, aberta e fechada por um único ator realizando uma ação não-verbal com o viewpoint de forma, transformou a dança que originalmente expressava um momento breve de fantasia confidencial do Porteiro em uma trajetória com espectro emocional bem mais amplo e intenso de sensações desse personagem. Para o ator que interpretava o Porteiro, essa porta poética permitiu inicialmente uma reciprocidade de proximidade, de intimidade e desejo, que o impulsionou à alegria pela expectativa correspondida e uma intensa embriaguez provocada pela ilusão momentânea de ter provado o primeiro beijo de quem se ama. Para quem assistia a cena, a ação da Ana Luiza gerou a impressão de que o beijo, materializado pela intensidade do desejo do Porteiro, fora apenas um sonho e ilusão. Uma porta poética de curtíssima duração, mas com grande efeito sobre a plateia e sobre o parceiro em cena.

Outro exemplo de porta poética criada neste momento foi quando o ator que interpretava o Porteiro, além de dançar, usou o viewpoint de repetição com as palavras da última frase do seu texto enquanto realizava a dança, gerando novas possibilidades de interpretação em justaposição à dança: 'Eu fiquei pensando. Eu... Fiquei pensando. A noite toda. Pensando... Eu... Você.... Eu e você. A noite toda. Eu e você a noite toda.... Mais uma vez novos e inusitados significados foram criados em cena. Se inicialmente o que aparentava ocupar o pensamento do Porteiro era o fato de que a Ana Luiza tinha dito que ele era bonito mas não sabia e o personagem se continha pela falta de intimidade entre os dois, com a porta poética, revelou-se algo muito mais intenso e carnal. É importante observar que o acréscimo desta nova circunstância interna de desejo sexual pela Ana Luiza não impediu o ator de demonstrar o que o texto propunha originalmente. Pelo contrario, acrescentou uma nova camada de significação complementar à já existente e possível para a cena mas que não necessariamente ocorria em toda a apresentação. Mais uma vez é preciso salientar a liberdade artística permitida pelo 
dispositivo. Como mencionado anteriormente, embora todos na equipe tenham que reconhecer e decidir como irão atuar diante de uma porta poética porque é um dispositivo realizado coletivamente, neste exemplo, duas portas poéticas foram propostas, abertas e fechadas individualmente.

Vejamos outro exemplo, presente na última cena do espetáculo, quando o Porteiro revela finalmente e de uma só vez tudo o que sente pela Ana Luiza. Novamente outras portas poéticas vieram à tona. Em sua declaração ele diz à Ana Luiza:

Eu briguei comigo porque te dei uma chave que abriu uma porta mas... acabou abrindo muito mais do que isso... Abriu um lugar em mim que eu não conhecia. Lá na alma. E eu gosto desse lugar. Agora eu me vejo completamente...completo. E isso é brega pra caramba, e eu nem sei mais o que eu estou falando. Mas não tem problema. O que eu quero dizer é que você é linda. E eu quero ser pra você tudo isso que você é pra mim. E mais! Que eu to numa felicidade que não cabe em mim. E eu quero muito dividir isso com você. Se você permitir. E tudo bem se você não quiser. Eu só quero que você saiba que você me deixa assim!

Neste momento quatro atores em cena interpretam o Porteiro e apenas um interpreta a Ana Luiza, que recebe a declaração do Porteiro sentada o mais próximo possível à primeira fileira da plateia.

Uma das portas poéticas criadas neste momento do espetáculo ocorreu depois que o texto 'você é linda' foi dito. Um ator começou a repetir num volume mais baixo e com entonações variadas a mesma frase, abrindo uma porta poética que se manteve como pano de fundo e justificativa para todas as outras coisas ditas pelo Porteiro. O texto se transformou numa ode à beleza da Ana Luiza:

Eu briguei comigo porque te dei uma chave que abriu uma porta mas... acabou abrindo muito mais do que isso... Abriu um lugar em mim que eu não conhecia. Lá na alma. E eu gosto desse lugar. Agora eu me vejo completamente...completo. E isso é brega pra caramba, e eu nem sei mais o que eu estou falando. Mas não tem problema. O que eu quero dizer é que você é linda. [Você é linda!] E eu quero ser pra você tudo isso que você é pra mim. [Porque você é linda.] E mais! Que eu tô numa felicidade que não cabe em mim. [Você é LIIIIINDAAAAAA!!] E eu quero muito dividir isso com você. Se você permitir. E tudo bem se você não 
quiser. [Você é linda.] Eu só quero que você saiba que você me deixa assim, [Linda]!

Enquanto nos exemplos anteriores as portas poéticas geraram micro ou pequenas adições e portanto dilatações espaço-temporais à cena, neste caso a porta foi aberta e se manteve aberta concomitantemente e em justaposição ao andamento do texto e do momento cênico. Ou seja, enquanto um ator optou por entrar na porta poética, os outros permaneceram fora dela, dando continuidade à cena. Nestes casos, mais ousados e arriscados mas não menos potentes, é fundamental que o(s) artista(s) que tenham aberto a porta poética fiquem muito atentos ao momento do seu fechamento pois a cena continua se desenvolvendo bem como a sua narrativa. É preciso cuidado para que o retorno não gere truncamento no fluxo da cena com por exemplo repetição incoerente, afrouxamento ou aceleração de ritmo indesejados, nem tão pouco um paralelismo competitivo com a narrativa da dramaturgia original. A poesia gerada pela porta não deve competir com nem perturbar ou tornar a cena original atrapalhada mas sim intensificá-la, potencializá-la com o frescor do improviso e explorações do que emerge momentaneamente.

Outra porta poética criada neste momento do espetáculo ocorreu nos ensaios antes da estreia e se tornou uma porta poética aberta com frequência durante as apresentações, sempre com conteúdos diferentes mas com a mesma função dramática e com materiais que variavam muito de acordo com o local da apresentação, a participação e disposição da plateia. Um dos atores que interpretava o Porteiro, após dizer o texto: 'E isso é brega pra caramba e eu nem sei mais o que eu estou falando' iniciou num rompante a musica É o Amor de Zezé di Camargo e Luciano (1991). Imediatamente os outros atores que também interpretavam o Porteiro começaram a cantar cada qual a sua música "brega", gerando uma celebração cacofônica mas inconfundível da breguice do amor. Frequentemente, após momentos de risos, a plateia se contagiava mais por uma das músicas que acabava sendo cantada em uníssono por todos. A plateia cantou juntamente com os atores no uso do dispositivo neste momento músicas como Amor I Love You (2000) de Marisa Monte, Não Me Deixe Só (2002) de Vanessa Da 
Mata, e em apresentações no Texas, nos Estados Unidos, My Heart Will Go On (1997) de Celine Dion e All of Me (2013) de John Legend, entre outras. O final da música eleita pela maioria encerrava de maneira espontânea o final da porta poética para todos e retomava-se assim ao texto da declaração.

Esta porta poética intensificava o momento dramático da cena a partir da inclusão de músicas populares e seus respectivos contextos culturais. A plateia, que muitas vezes erguia os braços e os balançava de um lado para o outro, adicionando à sua participação vocal uma performance física coletiva condizente, reafirmava a perspectiva do Porteiro em sua declaração de amor à Ana Luiza. Com o apoio da maioria da plateia, a perspectiva desta personagem e a pressão por uma resposta receptiva da Ana Luiza, também se intensificavam.

Embora Bogart e Landau não considerem a música como um viewpoint, este elemento é sugerido como um poderoso estímulo criativo e composicional (Bogart e Landau, 2005). Além disso, as duas autoras afirmam o desejo de que a publicação pelo assunto não seja absorvida como um manual de instruções prescritivas, mas sim de novas possibilidades, explorações e personalização por parte de quem o utilizar (Bogart e Landau, 2005). Portanto nada impede que a música seja usada enquanto elemento gerado pelos próprios atores em cena e até mesmo pelos atores com o público na composição em tempo real de um novo momento dramático.

É interessante notar que esta porta poética, diferentemente das examinadas anteriormente, era realizada com a participação do público e interdependente dele. Neste sentido, além da criação de múltiplos e/ou novos significados, ao cantarem todos juntos, o dispositivo permitiu também um senso maior de comunidade de todos os presentes, público e artistas, abraçando e performando juntos um dos subtemas do espetáculo: o lado brega e ridículo do amor. Frequentemente esta porta também tinha duração maior que as mencionadas anteriormente mas em última instância dependia de quanto o público queria e sabia cantar a música que ele havia selecionado. Ou seja, no caso de uma porta poética realizada com o público, a sua duração pode ser bastante variável pois dependerá da interatividade com ele e tanto sua abertura quanto o seu 
fechamento exigem maior delicadeza e sensibilidade de todos, pois precisam se apoiar no desenvolvimento e desdobramento da porta com novos colaboradores que não necessariamente sabem o rumo que a narrativa do espetáculo irá tomar. Os riscos para o bom andamento do espetáculo são sem dúvida muito maiores, mas se atentos ao momento presente e em diálogo franco e aberto com o público, os ganhos são nas mesmas proporções.

Os episódios acima não foram os únicos em que o dispositivo de portas poéticas foi utilizado em 0 Amor Que Habito mas representam exemplos da variedade e infinitude de possibilidades que o dispositivo permite. É importante observar que os exemplos acima estão todos relacionados à proposição de portas poéticas por iniciativa de atores, trajetória compreensível uma vez que atores e direção foram os primeiros a desenvolver e se apropriar do dispositivo. Como mencionado anteriormente, outros trabalhos da Coletiva Teatro também fazem uso deste dispositivo e em alguns deles, iniciamos o movimento de motivar o uso do dispositivo como possibilidade abarcada também pela equipe responsável por elementos cenotécnicos dos espetáculos, como iluminadores e sonoplasta, como nos exemplos abaixo.

\section{Abrindo novas portas: cenotecnia e interculturalidade}

No espetáculo Uma Sonata Familiar em 2018, a equipe de atores e equipe técnica era uma mescla de brasileiros e estadunidenses, o que gerou em contexto internacional e multicultural outros desafios. Entre eles o de ensinar o dispositivo em língua inglesa para um grupo com formação técnica bastante diferente e negociar a aplicação do dispositivo num contexto de prática artístico-cultural muito distinto do contexto da Coletiva Teatro. Em particular, onde a função denominada de Stage Management, uma espécie de braço direito da direção e gerente geral de todos os aspectos técnicos-artísticos, é de registrar por escrito

\footnotetext{
${ }^{5}$ O espetáculo foi uma coprodução da Coletiva Teatro com a Universidade Estadual do Texas e codireção de Nitza Tenenblat com o estadunidense Michael Rau. Sua estreia e primeira temporada foi em San Marcus, Texas, EUA 2018. Mais informações em http://www.coletivateatro.unb.br/index.php/pt/acoes-artisticaspt/espetaculos-pt/uma-sonata-familiar .
} 
todo o espetáculo com o maior rigor e precisão possíveis para a sua reprodutibilidade por outros artistas e técnicos. Este contexto implica uma complexidade maior quando o espetáculo prevê a possibilidade do improviso a qualquer momento. Neste espetáculo, portas poéticas por iniciativa da iluminação, vídeo

Figura 3 - Ensaio geral de Uma Sonata Familiar utilizando vídeo mapping. Foto: Thiago Sabino

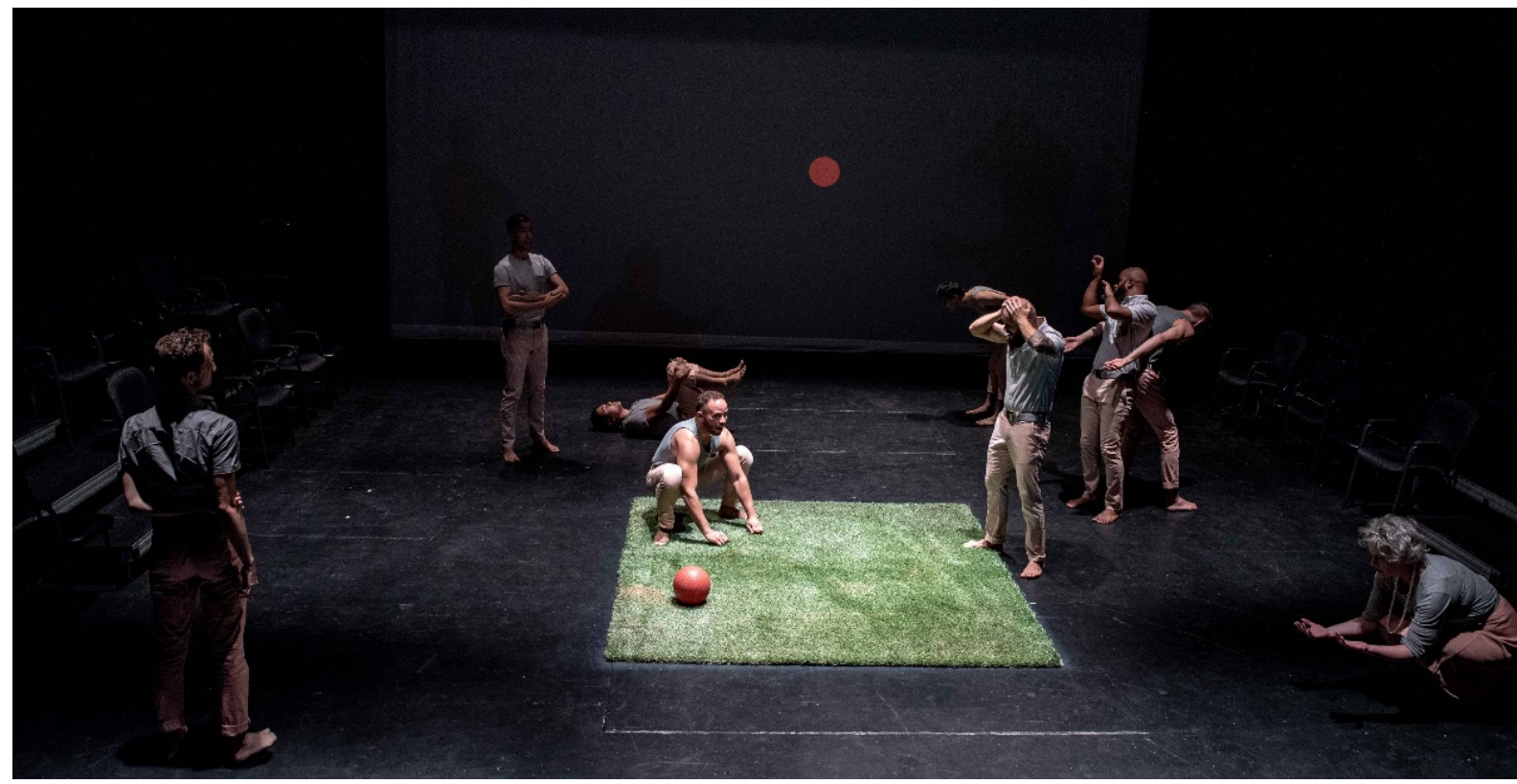

No registro acima, tem-se uma experimentação com bola cenográfica e bola projetada por vídeo mapping. Durante as apresentações a partir do seu computador, o vídeo mapper Thiago Sabino controlava a bola projetada e assim podia e cada apresentação, propor possibilidades totalmente diferentes de brincadeira para os atores e seus respectivos personagens nesta cena. Importante notar aqui que era necessário um diálogo e escuta cinestésica refinada entre Sabino e o iluminador Higor Filipe, uma vez que um pequeno acréscimo de luz utilizando refletores com potência muito maior do que a de um único projetor, causariam excesso de luz e acabariam ofuscando por completo qualquer projeção impedindo assim sua capacidade de abrir uma porta poética e consequentemente gerar novos significados em cena. Ao mesmo tempo, uma iluminação rebaixada 
sem projeção alguma causaria escuridão em cena e uma significação sem propósito claro.

Cabe também salientar que este trabalho foi realizado dentro de uma residência artística internacional realizada em loco e em parceria com o Departamento de Artes Cênicas da Universidade Estadual do Texas como parte do projeto de pesquisa Exercícios Interculturais de Criação em Coletivo para a Cena onde artistas estadunidenses e brasileiros intercambiaram experiências e modos de fazer teatral de maneira diária e intensiva durante o período de duas semanas ininterruptas. Esse contexto diário de colaboração permitiu uma situação muito particular e nova no modo de produção da Coletiva Teatro. Técnicos de luz, vídeo mapping e som, que não costumavam estar na sala de ensaio desde o primeiro dia de trabalho, puderam realizar exercícios com os atores e a codireção desde os primeiros momentos técnico-criativos. Assim estes técnicos - e artistas - também tiveram contato com o aprendizado e experimentação da técnica de portas poéticas repassada à equipe estadunidense e puderam dar seus primeiros passos em sua exploração no espetáculo. As implicações desta experiência do ponto de vista da pesquisa e criação artística são imensas no que tange à equidade de produção de significação entre as funções componentes do fazer no teatro performativo. Mas essa é uma outra discussão por completo, que embora muito interessante e importante, merece um espaço exclusivo para aprofundamento e apreciação.

Um ano depois, no espetáculo de contação de histórias para adultos intitulado Luar de Contos $1^{a}$ Edição $^{6}$, a sonoplastia criada e executada ao vivo por Glauco Maciel tipo foley encontrou espaço para a criação de portas poéticas juntamente com a atuação e contação de Jorge Marinho, que por sua vez criavam oportunidades novas de aprofundamento e intensificação de diálogo com o universo temático do trabalho, únicas e exclusivas para cada apresentação.

6 O espetáculo Luar de Contos 1a Edição teve sua estreia e primeira temporada no [referências sobre espetáculo da autora] em 2019 e faz parte do repertório da Coletiva Teatro.

Segundo Maciel todo o processo criativo de adicionar efeitos de som e sincroniza-los em tempo real a uma cena fílmica ou teatral denomina-se foley. Para maiores informações, ver referência Som e Silêncio de Maciel. 


\section{Urdimento}

Figura 4: 1a Edição de Luar de Contos, 2019, Centro Cultural Banco do Brasil, Brasília. Foto: Ana Carolina R. Leite ${ }^{8}$

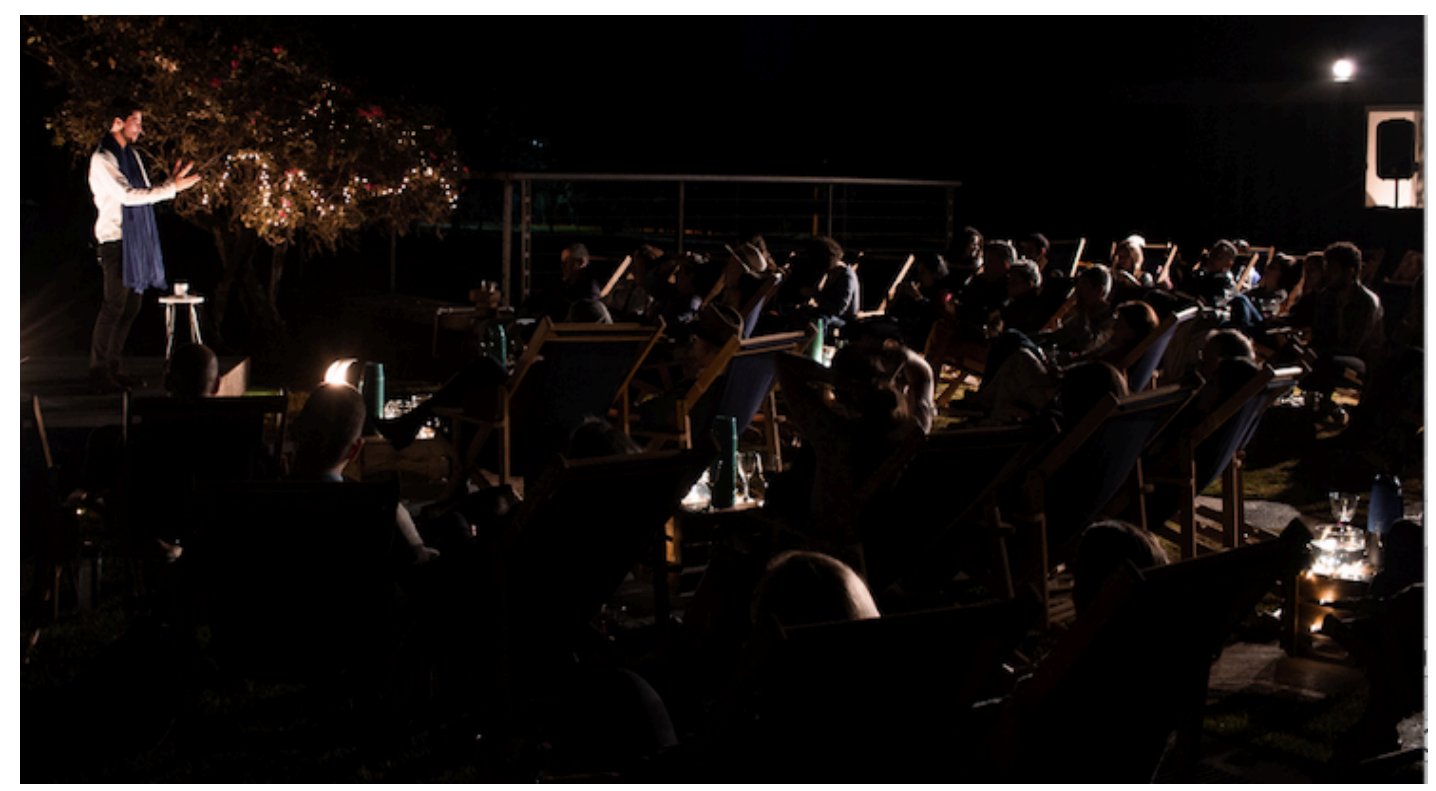

Figura 5: 1a Edição de Luar de Contos, 2019, Centro Cultural Banco do Brasil, Brasília. Foto: Ana Carolina R. Leite ${ }^{9}$

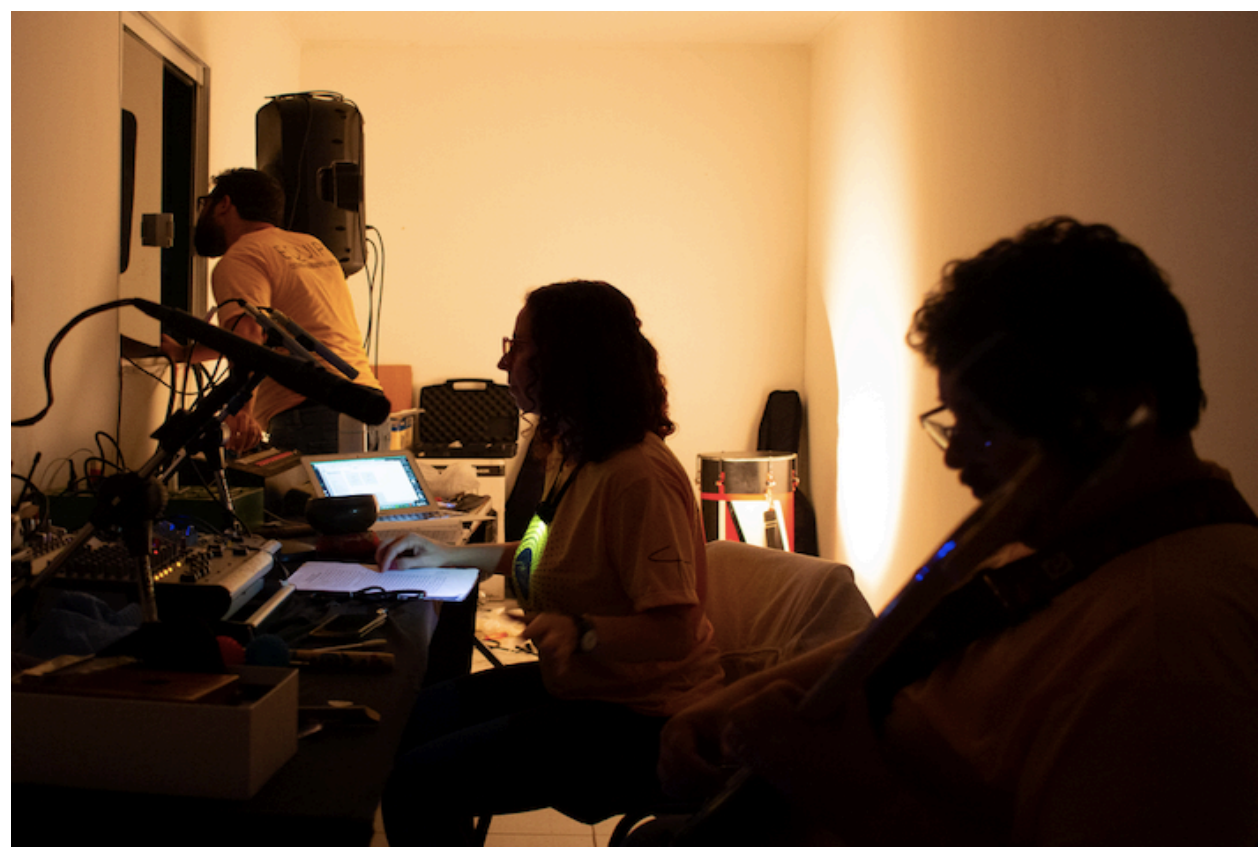

8 O ator e contador Jorge Marinho à esquerda em apresentação ao ar livre e contêiner técnico de som e luz à extrema direita, com caixa de som aparente na janela.

9 Imagem interna do contêiner técnico de som e luz de Luar de Contos 1a Edição. Da esquerda para a direita Higor Filipe (iluminador), Nitza Tenenblat (diretora) e Glauco Maciel (sonoplasta) realizando a sonoplastia tipo foley do espetáculo. 
As duas imagens mostram a distância entre o ator e contador e o sonoplasta e refletem o maior desafio encontrado para a utilização de portas poéticas nesse contexto. Como criar uma porta poética com início e finais claros e reconhecíveis para todos os artistas participando da apresentação se um deles (o ator e contador) não consegue enxergar o outro (sonoplasta)? Pode-se argumentar que no exemplo imediatamente anterior os artistas também não se viam, ou seja, atores estavam no palco enquanto vídeo mappere iluminador estavam na cabine. No entanto as proposições dos cenotécnicos eram visíveis e perceptíveis pelo tato aos atores, enquanto os técnicos na cabine tinham ampla e privilegiada percepção dos atores em cena. Ao mesmo tempo pode-se questionar se neste caso específico seria necessário que o ator e contador conseguisse enxergar o sonoplasta ou apenas ouvir suas proposições de portas poéticas para poder dialogar com elas. Mas como entender por exemplo se o silêncio é o início ou final de uma porta poética ou parte da encenação originalmente definida quando não se pode ver quem o está produzindo?

Estas são questões que ainda precisam ser aprofundadas e exploradas para que haja maior desenvolvimento das portas poéticas enquanto dispositivo entre as outras funções no fazer teatral. Possivelmente afete a disposição espacial, a atenção e a presença desde o primeiro dia de ensaio de todos os envolvidos numa produção. Certamente a falta deste exercício, que em última instância propõem para muitos uma inversão na cultura de propositividade permitida e desejada por iniciativa de artistas cenotécnicos, afetou a quantidade de portas poéticas abertas neste sentido. É importante também ressaltar que o sonoplasta, vídeo mapper e iluminador nestes casos, ocuparam tanto a esfera artístico-criativa quanto a cenotécnica de operação durante as apresentações, dando-lhes uma maior amplitude e grau de liberdade técnico-criativa em suas respectivas funções ao longo de todo o processo.

A partir dos exemplos acima é possível compreender como as portas poéticas respondem ao desafio original da Coletiva Teatro de manter a potência latente, o frescor e vigor do improviso do Viewpoints sem perder a contundência, 
precisão e solidez advindas de uma encenação cênica pré-estabelecido. Isso ocorre fundamentalmente porque as portas poéticas abrem espaço para momentos improvisacionais imprevistos inseridos num contexto cênico bastante estruturado. Observemos que os dois lados desta moeda não são novidade para o ator. Se considerarmos o momento improvisacional como impulso-intuitivo, sensível e o estrutural como racional pois implica capacidade de repetição rigorosa, nos aproximamos muito do paradoxo do ator levantado por Denis Diderot (1713-1784). No caso das portas poéticas as atividades não ocorrem simultaneamente e não há apaziguamento do paradoxo, que também pode ser interpretado como um reducionismo dicotômico das possibilidades criativas do ator. No entanto, é fato que o ator precisa lidar simultaneamente com o material criativo consolidado e a sua sensibilidade artística em tempo real em cada apresentação que realiza. E apesar do ator estar em estado diferente e a plateia ser única em cada apresentação e esses dois fatores serem motivos para cada apresentação ser ímpar em desempenho e afeto, é fato que o ator pode, ainda assim, cair na mecanização e automatização durante a realização do seu próprio trabalho criativo. É neste sentido que o dispositivo nos parece mais útil e relevante, pois permite que o ator lance mão dessas diferentes formas e fontes criativas e de sensibilidade à sua disposição com maior liberdade. A qualquer momento que sentir um impulso criativo, pode abrir, explorar e fechar uma porta poética; ou, pode permanecer na estrutura pré-estabelecida se preferir; ou pode variar alternadamente entre essas duas opções; ou ainda, entrar em portas poéticas propostas por outros artistas. Neste contexto a variação de estado do ator e a singularidade do público bem como o que emerge a partir da sua interação a cada dia e até no momento de cada apresentação são bem-vindos e atuam como trampolins para o exercício da capacidade técnico-criativa e sensível do ator.

Mas toda a liberdade das portas poéticas também vem com um preço que pode ser considerado alto por muitos. Antes de avaliá-lo, observemos que o dispositivo pressupõe uma estrutura dramática pré-estabelecida que de certa forma delimita um discurso existente. Essa delimitação não deve ser vista como limitação, uma vez que as portas poéticas podem utilizar e contribuir com o 
discurso com quaisquer materiais e/ou formas. No entanto, o preço que se paga ao utilizar este dispositivo e que acaba respondendo à segunda questão posta no início deste artigo é o seguinte: para manter uma equipe teatral envolvendo atores, técnicos, assistentes e diretora conectados e contribuindo em tempo real para uma cena com a sua respectiva atividade de maneira coerente e complementar diante de tanta imprevisibilidade criativa é necessário que todos os artistas envolvidos nas apresentações conheçam bem o texto, as marcas, as intenções de todos os personagens do espetáculo inteiro além do seu, bem como a função dramática de todas as cenas. É esta clareza com todo o material pré-existente que permite o reconhecimento do seu desvio, ou seja, de uma proposta de porta poética. Além disso, todos precisam estar conectados e afiados cinestésica e tecnicamente durante toda a apresentação para que as portas poéticas geradas não coloquem o parceiro, a cena e/ou a intenção do espetáculo em risco. Não falo aqui apenas dos riscos psico-físicos literais de segurança impostas por qualquer situação improvisacional e imprevista. É importante ressaltar que toda porta poética é performativa por natureza, o risco está sempre presente. Aqui, compreende-se o risco no mesmo sentido proposto por Josette Féral para o teatro performativo, onde "a escrita cênica não é mais hierárquica e ordenada; ela é desconstruída e caótica, ela introduz o evento [événement], reconhece o risco" (Féral, 2008, p. 204). A preocupação não é de incompreensão ou de uma complexificação de discurso que pode ser provocada pela porta, que aliás é entendida nesse contexto como ganho e vantagem gerados pelo dispositivo. A preocupação está no limite da conexão entre o discurso gerado pela porta poética, de ampla e irrestrita liberdade, mas que impõem uma escolha em tempo real para todos os envolvidos, e o discurso previamente estabelecido e delimitador do espetáculo no qual a porta se insere. Ou seja, independente da forma ou natureza material e imaterial que a porta poética adquirir, é preciso que ela tenha algum nexo com o material estrutural pré-existente para os artistas envolvidos. Essa conexão inclusive, é o que possibilita que os artistas possam responder, racional ou intuitivamente em tempo real, ao convite poético gerado pela porta. 
Aproveito este momento para esclarecer que uma porta poética não deve ser confundida com um programa de performance. Segundo Eleonora Fabião (2008, p. 237) "Performar programas é fundamentalmente diferente de lançar-se em jogos improvisacionais. O performer não improvisa uma ideia: ele cria um programa e programa-se para realizá-lo”. Um programa é uma estrutura em forma de roteiro de ação que é prevista e executada como tal em diálogo com as circunstâncias durante o momento da execução. A porta poética denomina uma ação artística inserida de maneira imprevista mas proposital num contexto de encenação que já foi estabelecido e é pré-determinado.

Para exemplificar melhor a diferença entre um programa de performance e uma porta poética, podemos examinar o Prólogo de O Amor Que Habito. Nas últimas linhas do Prólogo lê-se:

PROGRAMA: Atores verbalizam 3 características específicas presentes em mulheres na plateia e criam Ana Luiza em gestos e verbalmente, até chegarem na construção físico-corpórea da Ana Luiza, pronta para ir ao encontro do seu namorado.

A cada apresentação, os atores seguirão esse mesmo roteiro de ações, criando a Ana Luiza com gestos e verbalmente a partir de três características marcantes diferentes, todas extraídas de mulheres da plateia, presentes e visíveis a todos, ressaltando a beleza particular de cada uma. Unidas, essas características permanecem como vocabulário gestual dos atores e de representação para esta personagem até o final do espetáculo. A cada apresentação surge uma nova Ana Luiza, com características e gestual diferente e em diálogo com a plateia presente, mas esse programa se repete a cada apresentação e é previsto para acontecer no final do Prólogo do espetáculo. Já as portas poéticas, embora também possuam caráter improvisacional, são totalmente imprevisíveis e ao contrário deste programa, não são marcadas, podendo acontecer a qualquer momento do espetáculo. Mas retornemos ao cerne da questão, o preço que se paga pela liberdade criativa contida nas portas poéticas. 


\section{Considerações finais: portas poéticas e algumas implicações}

Como pode-se supor, saber de forma decorada o trabalho de todos num espetáculo exige muito mais trabalho e preparo da equipe do que contribuir apenas com 'a sua parte', o que impõem inúmeras condições de ensaio e um modo de produção quase impossível nos dias atuais. Talvez somente possíveis dentro do universo da pesquisa artística universitária. Mas essa é toda uma outra discussão que deixaremos para verticalizar em outra ocasião. Por outro lado, há uma vantagem sob a perspectiva da autonomia criativa neste modo de produção: ele permite que todos compreendam com maior profundidade o valor de significação e a função dramática de cada momento e material criado para o espetáculo. A título de exemplo, a ação de um ator pode ter maior valor de significação dramática num determinado momento do que a ação do sonoplasta. Ou vice-versa. O importante não é a diferença de valor dramático nos materiais gerados mas sim a consciência do seu valor, para uma maior instrumentalização, responsabilidade e intencionalidade criativa na hora de propor uma porta poética para o espetáculo. E quanto mais todos souberem o valor de significação dos materiais já existentes em um determinado momento para uma cena, melhores condições e domínio cada artista terá para abrir portas poéticas quando desejar e/ou responder às que forem propostas, gerando tantas novas conexões e camadas de significação poética para o espetáculo quanto forem desejadas.

Esse entendimento juntamente com o objetivo principal do dispositivo, que é de intensificar ou potencializar um determinado momento cênico, diminuem as chances de criação de portas poéticas frágeis, impossíveis e/ou irresponsáveis, que não sejam perceptíveis a todos os outros artistas, que não tenham nexo com a estrutura pré-existente, que trunquem o fluxo do espetáculo, ou criem sinucas de bico para os outros artistas. Por outro lado, o exercício contínuo do dispositivo numa história que todos conheçam bem traz ousadia, diversão e possibilidade de contribuição com uma outra camada de poesia gerada no memento atual da apresentação, a partir das circunstâncias momentâneas emergentes únicas e singulares disponíveis aos artistas envolvidos. E a possibilidade criada em 
improviso iniciada por um artista gera material rico e possibilidade criativa para todos. Lembrando sempre que em última instância o foco deste dispositivo cênico é o espetáculo, não um determinado artista; embora a potencialização do momento e consequentemente do espetáculo se dê pelos artistas que neles atuam.

Sobre a dramaturgia de um espetáculo com portas poéticas, respondendo à terceira questão colocada no início deste artigo, considerando a história préestabelecida como delimitadora e não limitadora do que pode ser criado em cena, a primeira característica que salta aos olhos é de uma dramaturgia plural, polifônica e que tem a cada apresentação uma parcela nova e original criada em tempo real. Ao mesmo tempo, pode-se dizer que a utilização das portas poéticas num espetáculo gera duas camadas dramatúrgicas. Uma mais fixa, tipo matriz, que por sua vez pode gerar diversas outras semelhantes e maleáveis como filiais da primeira, com pequenas alterações e novidades advindas de cada nova apresentação.

Outra observação interessante que pode ser feita é a relação que se estabelece entre o material pré-estabelecido e o novo criado com o uso das portas poéticas. Em O Amor Que Habito, a história que sustentava os personagens ficcionais principais era mais realista e linear; já as portas poéticas não tinham a linearidade como forma principal e frequentemente assumiam configuração simbólica, abstrata ou de devaneio. Neste sentido, as portas poéticas possibilitam espaço para entrelaçamento entre estilos ou tipos dramáticos distintos. Neste caso particular não havia limite nem intenção estilística para as portas, apenas uma fundamentação técnica (viewpoints) para a sua execução, mas a definição de uma intencionalidade particular para as porta poéticas não deve ser descartada como possibilidade criativa, que certamente irá impactar na dramaturgia.

O domínio técnico do dispositivo por parte dos artistas cênicos e a natureza performativa do dispositivo também acarretam outra consequência sobre a dramaturgia: seu uso consciente permite um grau de variabilidade performativa para o espetáculo. Ou seja, o uso de portas poéticas permite a escolha de se realizar um espetáculo com maior ou menor grau de performatividade teatral que 
claro, impacta sobre a dramaturgia. Esta consciência por si só se constitui como ferramenta muito potente em cena mas é preciso também lembrar que as portas poéticas não são introduzidas apenas quando a temporada de apresentações se inicia. Elas fazem parte dos ensaios desde o início da criação do espetáculo e quando utilizadas acrescentam um universo de conteúdo paralelo ao préexistente da cena que é continuamente lido em justaposição ao material existente. Durante todo esse processo as portas poéticas também servem como termômetro para avaliação constante da estrutura considerada fixa do espetáculo. Uma porta poética ocupa um lugar espontâneo, pontual e alavancador do material existente. Do ponto de vista dramatúrgico, se ela passar a ser maior que a cena em si, é um sinal de alerta. A porta poética pode estar descarrilhando ou extrapolando o nexo do discurso do enredo ou, pelo contrario, sinalizando a descoberta de algo novo e fundamental que deve ser investigado e ter seu lugar assegurado como parte da estrutura que se tornará pré-estabelecida durante as apresentações. Desta maneira, o trabalho com portas poéticas permite uma vantagem interessante para trabalhos criativos coletivos: permite a constante revisão e frescor dramatúrgico do espetáculo, tanto durante a sua criação, quanto durante as apresentações.

Finalmente é preciso examinar o desafio mais delicado de todos: a plateia acompanha e se conecta com uma dramaturgia com portas poéticas? Ou, ao inserirmos tantas possibilidades criativas, paralelas e por vezes não-lineares e tangenciais ao longo de uma apresentação perdemos a história que tentamos contar? Que espaço é esse que as portas poéticas permitem adentrar? Talvez a forma mais imediata de responder a essa pergunta seja pela interatividade das plateias com o espetáculo observada durante as apresentações; o esgotamento, acréscimo e novo esgotamento de ingressos da temporada de estreia; ou o interesse pelo trabalho e pelo dispositivo em terras distantes estadunidenses e gregas, que permitiram um diálogo para além das diferenças criadas pelas línguas. Mas essa resposta soa narcisista e rasa quando o interesse é pela exploração de dispositivos técnicos coletivos no teatro performativo. Neste sentido também não 
parece útil adentrar a teoria da recepção para examinar como e se o espetáculo é recebido.

Sob o aspecto da comunicabilidade, uma das grandes vantagens das portas poéticas nos parece a simultânea amplitude e verticalidade que elas possibilitam ao momento do encontro entre artistas, espetáculo e plateia. O favorecimento daquilo que pode ocorrer no encontro teatral e a sua especificidade materializada no aqui e agora pelas múltiplas sensibilidades poéticas de e entre artistas e plateia, tornando-os reconfiguradores contínuos de singularidades poéticas. Assim, o presente em sua materialidade e imaterialidade é literalmente recebido como presente durante o encontro, abrindo possibilidades e espaços-tempos únicos, que jamais seriam explorados se não fossem a sensibilidade e especificidade do momento presente, composto exclusivamente aqui e agora por cada um dos presentes.

Do ponto de vista mais amplo se, como diz Fischer-Lichte, o poder transformador da performance no teatro está na poética própria gerada pela interação entre artistas e espectadores, que engendra performance e o fenômeno da emergência; ou ainda, se como sugere Dubatti, o teatro é a experiência-evento onde convivência, poiésis e expectação interagem, então necessitamos de ferramentas e dispositivos técnicos e criativos que utilizem estes elementos. Precisamos de dispositivos que incluam interatividade entre os presentes e incluam interatividade entre o que emerge fruto desta presença com o material criativo. E estes dispositivos precisam utilizar estes elementos não como meros acasos resultantes de uma convivência momentânea, mas sim de maneira técnica para que o teatro performativo ocorra e efetive seu potencial transformador. Teatro performativo se faz com e para o espectador; não apenas para.

Do ponto de vista das técnicas e métodos teatrais - em particular para atores mas também para cenotécnicos e diretores - isso tem implicações significativas. Não basta apenas ter consciência da expectação ou da convivência e fenômeno da emergência na autopoiesis. É preciso conseguir treinar esses elementos e utilizá-los tecnicamente em cena. As portas poéticas são um exemplo concreto desse tipo de dispositivo, tanto pela natureza coletivizante que impulsiona a 
interatividade, quanto pela utilização do que emerge no momento da interação (entre artista e espectador, entre artistas ou entre espectadores) de maneira técnica como trampolim criativo. Indicam também, um caminho possível para a sistematização de outros tantos dispositivos e ferramentas que geram performatividade em cena, necessários se queremos expandir a acessibilidade, uso crítico e potencial de impacto transformador do teatro performativo contemporâneo.

\section{Referências}

ARAÚJO, Glauco Francisco Maciel de. O Som e o Silêncio: A Influência e Condução do Efeito Sonoro à Cena Filmográfica. Monografia de Pós-Graduação em Cinema e Linguagem Audiovisual. Brasília: Universidade Estácio de Sá, maio 2018.

BOGART, Anne e LANDAU, Tina. The Viewpoints Book: A Practical Guide To Viewpoints and Composition. New York: Theatre Communications Group, 2005.

DUBATTI, Jorge. O Teatro dos Mortos: Introdução a uma filosofia do teatro. Trad. Sérgio Molina. São Paulo: Edições Sesc São Paulo, 2016.

COLETIVA TEATRO. O Amor Que Habito. Direção Nitza Tenenblat. Performers: Nei Cirqueira, Jorge Renan Mendes Marinho, Pedro Henrique Silva Lopes, Alexandre Batista da Silva e Iuri Pereira dos Santos. Brasília: Centro Cultural Banco do Brasil, abril de 2018;

COLETIVA TEATRO e TXST. Uma Sonata Familiar Amor Que Habito. Co-direção Nitza Tenenblat e Michael Rau. Performers: Nei Cirqueira, Jorge Renan Mendes Marinho, Pedro Henrique Silva Lopes, Alexandre Batista da Silva, Daniel Aguilar, Derek Miller, Ethan Santo, Laura Lane, Matthew Ngyuen. San Marcos, Texas, EUA: MainStage Theatre, julho de 2018;

COLETIVA TEATRO. Luar de Contos 1a Edição. Direção Nitza Tenenblat. Ator e Contador de Histórias: Jorge Renan Mendes Marinho. Brasília: Centro Cultural Banco do Brasil, maio de 2019;

FABIÃO, Eleonora. Performance e Teatro: poéticas e políticas da cena contemporânea. Sala Preta, São Paulo, v. 8, 235-246, 2008.

FÉRAL, Josette. Por uma Poética da Performatividade: o Teatro Performativo. Sala Preta, São Paulo, v. 8, 197-210, 2008. 
FISCHER-LICHTE, Erika. The Transformation Power of Performance: $A$ new aesthetics. Trans. Saskya Iris Jain. New York: Routledge, 2008.

TENENBLAT, Nitza, CIRQUEIRA, Nei, MARINHO, Jorge Renan Mendes, LOPES, Pedro Henrique Silva e SILVA, Alexandre Batista da. O Amor Que Habito. Texto ainda não publicado, 2018.

Recebido em: 30/06/2020

Aprovado em: 26/08/2020 